\title{
Child as Educator: Introduction to the Special Issue
}

\author{
Joanna Haynes • Karin Murris
}

Published online: 10 March 2013

(C) Springer Science+Business Media Dordrecht 2013

In the context of our research and professional development work in education we have become aware of views, from a small minority of professionals, that position children as uniquely insightful or wise, by virtue of their being newcomers and novices in the world: assigning children a kind of chronological advantage. This positioning characterises children as being highly 'present' to the here and now; as having a tendency to press others with urgent questions about the world; as expressing originality and freedom of thought; creative use of language; imagination and flexibility of mind. We have sometimes bumped into a kind of reverence for what emerges, particularly when adults are engaged in exploratory conversation or, for example, the practice of philosophising with children. The child as 'natural' learner, or 'natural' philosopher, have sometimes been held up as models to which adults might aspire, to remember what has been forgotten or recapture what has been lost through ageing away from childhood. It seems to suggest that adults can re-kindle that 'original' curiosity or that listening to children, or the 'child within', as the means to such an end: a kind of re-birthing. Such 'childlike' ways of being are associated with aesthetic, meditative, wild and playful, creative modes of knowing and re-presentation. By contrast with the reverential view, and at the other end of a spectrum of beliefs concerning children's capacities, we have come across many teachers and teacher educators who advocate rigid stage theories of child development and curricula. Their rationales are that children are simple, concrete thinkers, prone to fantasy, and that complex, abstract and rational thinking only comes with age or physical maturity.

Among some academics and practitioners there has been a strong move away from ways of thinking about children's capabilities that start from what children are perceived to lack when compared to adults: a deficit model. The contributions to this special issue continue this trend and tend towards the view that children's capacities to educate themselves and others are often underestimated. Some practitioners describe children as particularly perceptive or

J. Haynes $(\bowtie)$

School of Education, Plymouth University, Drake Circus, Plymouth PL4 8AA, UK

e-mail: joanna.haynes@plymouth.ac.uk

K. Murris

School of Education, University of Cape Town, Rondebosch 7701, Cape Town, South Africa

e-mail: karin.murris@uct.ac.za 
insightful, or as having 'fresh eyes' to look at the world, or the courage and freedom to ask political questions about humanity in the world. We have noticed that teachers sometimes struggle with allowing children to voice their opinions and ask 'awkward' questions, and that when this happens adults tend to respond with nostalgia, admiration, anxiety or distaste. As children are invited to tender their speculations and assured that their teachers will listen and take them seriously, the mirror images of adult reverence and awe are confusion, sentimentality or cynicism. Professionals in the compulsory education sector often experience great uncertainty when faced with the unexpected or with troublesome issues such as death, loss, politics, religion or sex and sexuality, and often seem to be at a loss as to how to mediate the various dimensions of their role as guardians, guides, listeners, co-enquirers and teachers (Haynes and Murris 2012).

We are living through a period in the politics of childhood and education in which pedagogical relationships are being re-imagined and re-configured under the influence of various social changes. For example, reference to the 'digital age' features in current 'future orientated' policy discourses about the ways in which education needs to respond to wider social developments. It is an interesting case when it comes to the theme of child as educator. Digital technologies and virtual social networks are sometimes associated with pedagogies of resistance created by young people. In addition, the digital and virtual networking worlds are examples of domains in which some adults feel left behind and in need of teaching by younger so called 'digital natives'. Critics of this thesis argue that such labelling tends to use broad assumptions about age to over-generalise about characteristics and relations to technology and social networks of particular generations, ignoring other diverse social characteristics of the age group.

What do these responses signify? We do not believe that such contradictions and uncertainties are confined to the kinds of pedagogies that actively encourage student participation and classroom dialogue. Educational processes that operate on the basis of co-construction of knowledge, provisional understanding and the fallibility of the teacher may be more likely to throw up questions about who has the answer or who is 'leading the learning'. However, we believe that a lack of confidence in professional judgement reflects deep and widespread ambivalence in educational relations between children and adults. This has a profound impact on all aspects of education. In the contexts described it has led to questions such as Who is doing the educating? and How do we understand the educational relationships between adults and children? Campaigns for the institutionalisation of children's rights have begun to influence educational processes. In some contexts, teaching about children's rights and responsibilities has become a new form of school discipline and regulation enabling 'positive outcomes and low costs' (Sebba and Robinson 2010, p. 6).

In proposing the theme of 'child as educator' for this special issue, and preparing our call for papers, we speculated about the reasons for some of the responses of practitioners described above, and their origins. The aim of this issue is to critically examine particular theories, cases and examples that can help to illuminate important dimensions of pedagogical relations in education. It has not been our intention to invite others to help us re-create any universal, definitive or essential conception of child or childhood.

\section{Antecedents and Examples of 'Child as Educator'}

In our original invitation to potential contributors we identified a number of possible avenues of enquiry in examining the idea of 'child as educator' and these ideas were 
included in the invitation to tender contributions to this special edition of the journal. These are very briefly sketched below.

\section{Starting from the Child}

Historically, the notion of 'child as educator' might be associated with naturalism and Rousseau's call to preserve the child's original and perfect nature. His idea of the intrinsic value of childhood and of child as primitive innocent has some echoes in the kinds of "wise child' constructs described in the opening paragraph above. For Rousseau the impetus for learning is aligned with the so-called 'natural development' of the person: a view that positions the educator as an enabler of learning whose focus is on arranging the environment and creating conditions for growth. In this sense learning is led by the child, who in turn is led by his or her natural instincts, rather than by wider cultural practices. According to Rousseau women tend to be 'weaker' than men, so his appeals to nature can imply not only radical but also deeply conservative tendencies in his educational perspectives (Stables 2008, p. 69).

At the turn of the eighteenth century, Pestalozzi's rejection of bookish learning and Rousseau's rejection of coercive and authoritarian educational methods influenced the progressive advocacy of the educator starting from the child. In its emphasis on sense perception and direct experience it appears to be at odds with contemporary approaches that emphasise young children's capacities for reasoning and dialogue. On the other hand, the progressive insistence on children's freedom to roam and discover things for themselves rests on the idea of individuals constructing their own realities, understandings and meanings, as they explore the environment.

\section{Children as Co-constructors of Understanding}

Constructivism positions human beings of all ages as sense-makers, actively engaged in conceptualisation and meaning-making, in ways that have the political potential to recognise children's agency and authority in respect of their thinking and experience. For Dewey it is what teachers do with experience that transforms it into something educational. Theoretically children can be positioned as knowledgeable 'equal partners' in the co-construction of understanding, even if less experienced in terms of quantity of experience. There is a fair degree of rhetoric regarding collaborative learning, group work and classroom discussion or dialogue, but in compulsory schooling and curricula adults tend to assume the authoritative role of the more knowledgeable and competent in ways that can trivialise or disregard young people's personal knowledge and experience, even when it is not intentional. The preoccupation with age difference and sorting children into classes according to their dates of birth is often an obstacle to thinking in terms of reciprocal and intergenerational education. It is worth imagining how educational relations between teachers and their students might be reconfigured to take account of both ethical and epistemological grounds for children's inclusion in forms of education that take their perspectives more clearly into account.

\section{Children in Peer Education}

There are some illuminating historical examples of children's roles as educators in the context of the development of mass education. Joseph Lancaster (1778-1838) introduced the monitorial system in England, where older and more advanced students taught younger and less advanced pupils; a system that allowed larger numbers of students to be educated 
at the elementary level at a much lower cost. The rationale was not only that this was cost effective but that older students were closer to the capacities of their pupils.

In the first place, it is evident that on this system children are better taught than on the old, because from the sympathy they take in each other, they learn everything communicable by one to the other more easily and perfectly. Whatever a child has been taught, he will communicate to his companions better than a master; because his manner of teaching, and the words he employs, will be suited to the capacity of his pupil; he knows where this difficulty lies, and how to remove it. (Lancaster 1824)

A further argument for the efficacy of this system reflected the belief that teaching is a way of consolidating and developing the knowledge of those who teach.

(T)he knowledge of the monitors themselves expanded, confirmed, and perfected by the practice of communicating it to others. Qui docet, discit (He who teaches, learns) is probably as true a maxim in its application to young people, as ever was uttered. (Griscom 1825)

Peer education became very popular in the 1990s, particularly in health education (Turner and Shepherd 1999). There are many examples in all sectors of formal education and in informal education activities such as youth work. On the whole such initiatives in formal education are more likely to be part of mainstream schooling in 'western' countries. Typically, peer education pedagogies are used in drugs and HIV/aids education, sex education, anti-racist education, rights education, peace education, peer mediation and conflict resolution.

A 'cascade' model, involving peer education (adults train older children who then work with younger children), is sometimes associated with UNICEF's more recent Rights Respecting Schools project (unicef.org.uk) and, as such, children and young people are often involved in producing resources to promote children's rights in schools. The educational materials produced by UNICEF (2010) are promotional materials. School display posters on 'our rights and responsibilities' often look uncannily like older versions of 'our classroom rules.' What is disconcerting about evaluation reports of such initiatives (for example Sebba and Robinson 2010) is their unwavering, almost evangelistic enthusiasm, along with their uncritical association with instrumental school improvement discourses of better behaviour, better attitudes, better results.

One of the interesting features of many peer learning schemes is that they often seem to be introduced when adults are unsure how to proceed or when the subject matter is troublesome. In the context of the theme child as educator we wonder what is signified by moves to approach education on such morally and politically significant topics with adults at a distance, but retaining control over the curriculum and pedagogy. Official peer education models are often developed, led and controlled by professional adult educators. Child/young person led peer education does take place in schools, but it is not always recognised. The notion of peer education has been thoroughly critiqued by Frankham (1998) for its tendencies to treat young people as a homogeneous group and to stereotype them as more susceptible to peer pressure than other age groups. She does not dismiss peer education altogether but questions whether it genuinely puts young people in greater control of both the content and process of education.

\section{Archetypes of the Wise Child}

Not unlike the children as digital natives notion, in contemporary children's literature it is not unusual for child characters to be portrayed as cleverer, more intuitive and powerful 
than their parents or the adults around them (Gaiman and McKean 2003), or more attuned with the urgent social and political questions of the day. Bradman's and Ross's Michael (2009) ignores the school curriculum in pursuit of his interest in rockets and the conclusion shows how much smarter he is than his teachers. Colin Thomson's picturebook How to live forever (1995) features the character of the Ancient Child who has read the book containing the secret of how to live forever and who remains frozen in time at the age of 11 . Peter, the main protagonist in the story, chooses not to read the book but rather to return to the world, appearing supremely wise (see Haynes and Murris 2012 for more examples).

Content analysis of the most enduring works of children's literature suggests that the narratives are made possible by the very absence, neglect, incompetence or distraction of the adults in the worlds of the leading child characters. One interpretation of this recurring scenario might be that children can only really learn and make the transition to adulthood without the surveillance or interventions of adults, or that the heroes and heroines of children's literature are those that have internalised the characteristics of the morally sophisticated and reflective mature adult.

\section{Children's Rights}

Contemporary politics of children's rights position children as agents of their own destiny, as being driven to become autonomous individuals, as needing to be listened to in order for such an autonomous self to come into being. In the current climate of revelations about the abuse of children in many institutional settings there is evidence of moral panic and guilt, at past failures of adults to believe children and take them seriously. There is a growing literature on the creation of conditions for hearing children's voices in all areas concerning them and particularly in institutional contexts (Clark et al. 2003; Rudduck and Fielding 2006). There seems to be considerable confusion in policy and practice associated with managing children's authority in respect of their experience, knowledge, interests and wishes.

\section{Themes in the Contributions to the Special Issue}

So far we have outlined some historical and contemporary themes shaping understanding and interpretations of the notion of child as educator. In the remainder of the introduction we comment on what the contributors to this special issue have brought to the table. This special issue contributes to the interdisciplinary dialogue about children's different roles and positions in education. One of the aims is to seek conceptual clarifications of some core concepts and relationships. The other is how these conceptual enquiries offer different perspectives on the theme 'child as educator'.

\section{Theme 1: Problematising the Idea of 'Child ${ }^{1}$-as-Educator'}

Each author offers a different way of thinking about the concepts involved in the phrase 'child-as-educator'. The 'figure' of child and the theme child-as-educator are powerfully

\footnotetext{
1 We have adopted the use of 'child' without including an article 'the' to try and distance ourselves from the practice of talking about 'the child' as having a set of essential and universal characteristics, and often resulting in the marginalisation of children, but still to allow discussion of the concept: 'child'. 'Children' denotes particular children, living in particular times and places.
} 
deconstructed by Erica Burman who offers a meta-analysis of some theoretical influences that continue to dominate policy and practice in education. She starts this special issue with a welcome critique of its theme. Her commentary about what it might mean to attempt to address the notion of 'child as educator' argues for caution. In her concern to dismantle any romantic or sentimental affiliation with the idea that child can educate, she suggests that instead of essentialising 'child', we should use the plural 'children'. Such a proposal foregrounds children with bodies located in space and time whose understanding, and our understanding of 'them', is always situated and specific and therefore resists any kind of abstractions, such as essentialising notions of child. Burman asks to whom the project 'child-as-educator' belongs. She is an advocate of intersectionality, arguing against abstractions of child and for the specificity of concrete positions and situated relations. She draws on intersectionality as this term informs her analysis of theory and practice that involves, as she puts it, people's 'multiple positioning' across 'axes of gender, class, racialisation, able-bodiedness, sexuality, and more'.

Throughout the special issue, a number of claims are made about specific educational relationships and children's role of educators within those relationships and these claims help to problematise the idea of child as educator (see Fig. 1 below).

The diagram is a visual representation of contestable educational positions that might be assigned to children or that some children take up in particular contexts. Each author emphasizes different kinds of educational relationships and, by implication, assigns different roles to children as educators. In their case studies, Murris, Johannesen and Dixon all portray the children as actual or potential teacher educators, thereby challenging existing curriculum design and educational policies. Haynes argues that children act as co-educators in the context of participatory and therapeutic community education projects and as

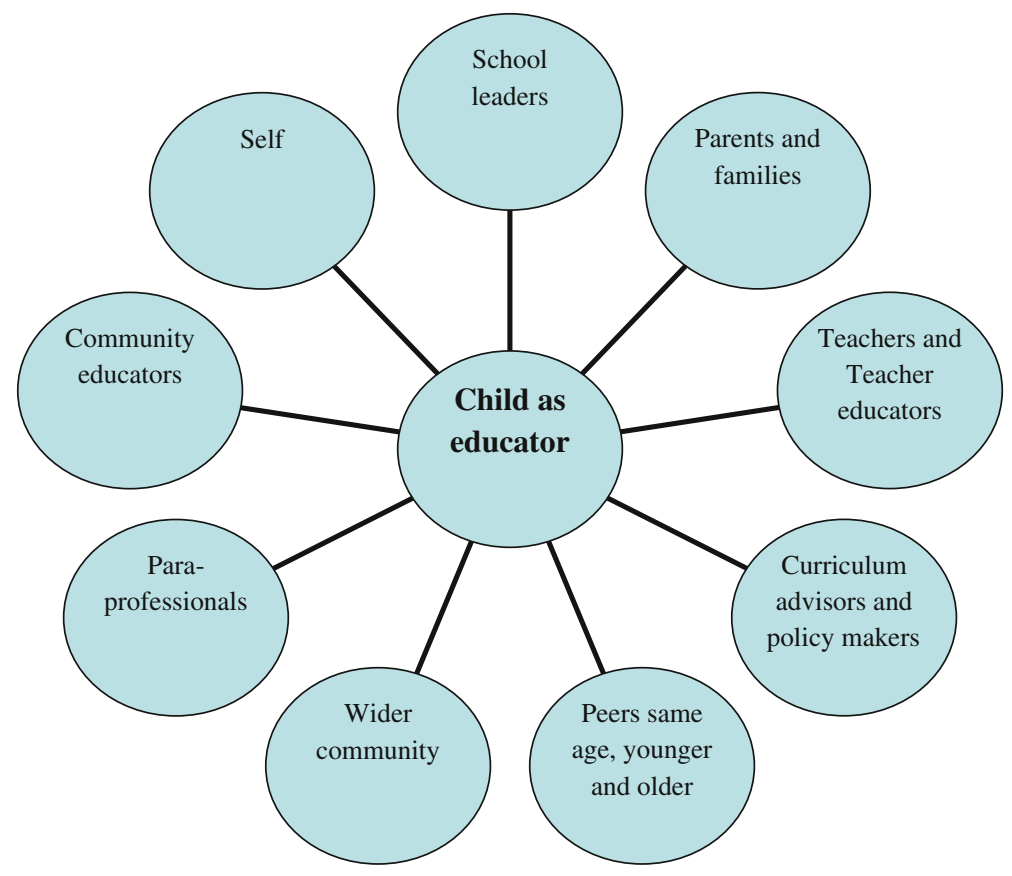

Fig. 1 Constructions of children as educators 
catalysts for wider community engagement and culture creation. Children are also reported to be peer educators in a number of the papers. In one of Anglin-Jaffe's case studies the children are not only their own educators, but also teach one another in the use of sign language in their private worlds, generating child-led oppositional pedagogies in the context of their teachers' repression of sign language in classrooms.

Walter Kohan's paper is refreshing in that he presents a 'philosophising' approach to academic writing-rather than a 'review the field' approach. This last contribution also profoundly questions the politics involved in the concept of child, by focusing (like Socrates) on writing itself, the unique role of philosophy in education and also on the value of 'being child' as a philosopher. For Kohan the concept child does not signify a chronological stage, but an experience of being. Kohan posits the condition of childlikeness within an account of the philosophical life-asserting its value to philosophy, affirming the value of the search itself (rather than the product of it) and the condition of not-knowing. As readers we feel these characteristics of childlikeness through the author's description of what things are not-rather than what they are.

\section{Theme 2: Conceptualising Education: Individuality and Age}

Apart from focusing on the phrase 'child-as-educator', all contributions challenge the idea that learning should be conceptualised individualistically, that is, as something that happens 'in' an individual, either biologically or psychologically (or a combination of the two). Instead of offering conceptions of education that involve Cartesian dualistic 'inner/ outer' orientations (Murris 2012), they propose that individual teaching and learning needs to be looked at in terms of involvement in social and cultural practices. What is clear from their examples is that what it means to educate depends on how we conceptualise the relationships between individuals and therefore 'individuality' and 'subjectivity'. What influences the meaning of such concepts are common assumptions about clear boundaries between individuals (not only by their skin, but also in other than physiological terms; (see for example Lakoff and Johnson 1980, 1999) and as a result learning should not be understood as a mental process that takes place 'in' the body of a person and as something that can be assessed by focusing on what individual ' $x$ ' learned from individual ' $y$ ', who intentionally taught what ' $x$ ' has learnt. By focusing on socio-cultural practices the authors open up possibilities to make visible what often remains invisible in theories of education, that is, to be sensitive to the contexts in which learning takes place (including the material contexts; see e.g. Lenz-Taguchi 2010) and what happens in 'between' people in different pedagogical relationships.

A rethinking of individuality and the relationship between body and mind opens up opportunities to explore the importance of age, race and physical abilities of the body that claims (or claimed on their behalf) to educate. Rich concrete examples of social and cultural practices are presented from England, Norway, Nicaragua, the USA, Thailand and South Africa. All authors suggest the idea, explicitly proposed by Johannesen, of 'forgetting about age' and with it addressing the difficulty of adults listening to children, through intergenerational conversations that are, for example, mutually educative in a community education setting (Haynes). It makes us think of education as not receiving what is already 'given' (existing bodies of knowledge), but foregrounds education as the co-creation of culture, as Freire suggested. Haynes's autobiographical reflections on her experiences in England in 1980s are, at one level, remote from the experiences of an early childhood educator in Norway but, at another level, connected with Johannesen's experiences in an early child care setting. In Johannesen's Norwegian research setting, her field 
notes indicate how 1-3 years old educate their teachers through bodily and non-verbal expressions and challenge ('accuse') their observers to reconsider that they are 'too young', thereby opening up new ways of thinking and being with young children. Through their bodies the children force the educators to 'answer' and in doing so challenge the normal power relationships of this early years classroom.

Shifting the emphasis in thinking about education through the lenses of individualistic notions of subjectivity such as personal feeling, value and emotion, mobilises educative relationships where the teacher can educate 'even' when s/he is very young. These young educators bring about changes in thought, feeling and/or action that are judged to be worthwhile for discerning older people. In her chapter, Murris examines the ethicopolitical dimensions of this concept of 'worthwhileness' in more depth. She argues that the emphasis on educational relationships removes the necessary conditions of 'intentionality' and 'worthwhileness', in contrast to some educational theorists who insist that they are necessary conditions for what counts as 'education'-but typically 'education' understood in an individualistic sense. Peters (1966) has famously pointed out that not all cases of learning are educational, but this claim only holds when education or learning is understood as something that happens 'in' a person who is subsequently 'in some way affected or "transformed" by this knowledge' or understanding (Barrow 2009, p. 16), as argued above. This begs the ethico-political question, of who decides what is 'worthwhile' or 'transformative'.

Kohan puts the transformative power of teaching and learning in the Socratic context of questioning and unlearning what we (think we) know. For him philosophy helps to build a relationship with knowledge and an engagement with those questions that cannot be answered. This practice of philosophy is not knowledge but a particular childlike relationship to knowledge. Like other contributors, Kohan argues that the worthwhileness of educational exchanges is still dominated by the privileging of the written word over the spoken. In their own different ways all the papers challenge this narrow focus on knowledge construction and knowledge representation, which is another theme that runs through this special issue.

\section{Theme 3: Language/s, Concepts, Thinking and Representation}

It becomes possible to regard particular groups of children as educators when we take into account multi-modal ways of creating and representing knowledge. All the examples in this issue talk about young children-some as young as one year old. The papers describe young children who are inclined to express themselves informally through their bodies, rather than exclusively or mainly through oral language: they express their thinking and communicate through physical movement, playful bodily resistance, playing with ideas, drawings, sounds, sign language — often outside mainstream classrooms, in playgrounds, community buildings, corridors, or special schools.

Anglin-Jaffe's chapter on signing and the invention of language outside the classroom also adds to the wider discussion about discourses of language use, power and authority in educational settings. In her writing she follows an established academic convention by using the capital ' $D$ ' in 'Deaf' deliberately 'to signal the cultural identity of a community of people united by sign languages' and as a means 'to highlight the socially constructed nature of deafness', in contrast 'to 'deaf' with a lower case 'd', which is used to refer to the audiological understanding of hearing loss'. She shows through two case-studies of schools for Deaf children in Thailand and Nicaragua how oralism is a practice of domination and involves a disciplining of children's bodies through repression of non-verbal forms of 
communication and children's resistance to it. Without overstating the case, she argues that signing practices initiated by the Deaf young people could be built upon by educators in the effort to recognise and value the knowledge that learners can contribute to the educational process. Hannah Anglin-Jaffe's case of Deaf children as peer educators, draws out the wider possibility of more inclusive education, through critical pedagogy. In her examples, the adult educators are failing to hear Deaf children. Similarly, in Murris's chapter, adult educators are not really listening to children when they watch their contributions in film footage of a philosophy with children lesson. Instead, they use language to misread, sentimentalise or marginalise children's ideas.

In terms of the disciplining of children's bodies and the resulting unequal outcomes there is a clear link between Anglin-Jaffe's and Kerryn Dixon's contribution when she discusses social control and 'body management'. Using a Foucauldian lens she argues how bodies are managed and disciplined in a mainstream South African literacy classroom where child is absent and invisible. Dixon argues that children can teach the student teachers (and therefore the teacher-educators who guide them) who are observing them from the back of the classroom.

\section{Conclusions: Children as Educators}

Burman's critical commentary about the ownership of an academic project that involves answering the question 'Can child educate?' provokes the reader to reflect on the essentialising involved in the language of the question itself. All authors, however, seem to manage to avoid this danger by describing and theorising practices that, they propose, are educative. The way in which their practices can be called 'educative' and with children positioned as educators have striking commonalities. They foreground ageless relationships which render adult/child centered dichotomies redundant and out-of-date. These relationships are educative because not only learning takes place, but also the transformative nature of what happens in the (in)formal spaces where children and adults meet, is re-cognised and ac-knowledged, that is brought to consciousness through careful observation and reflection. Johannesen puts it powerfully when she argues that (teacher) education is more than (individual) learning, and about 'coming into presence' as professionals.

What strikes us in the contributions is a blurring of boundaries and challenging of binaries between community and individual, child and adult, therapist and client, and with it a dissolving of the subjectivities involved in who is teaching and who is learning. Central to the discussion is the question of how adults listen to child(ren), ranging from a questioning of the 'listening for' and the necessity of 'listening to' children emergent from the world of play therapy (Haynes), to the epistemic injustice involved in accommodating the needs of Deaf children (Anglin-Jaffe). Unlike Johannessen's case study where the children are seen as 'too young', the South African children in Murris's example are 'too dark skinned and too poor' to deserve epistemic equality or epistemic trust-stereotyped as being 'lazy', untrustworthy and 'sneaky' they are believed not worth listening to.

This special issue contains not only arguments for children to be recognized as co-educators (Haynes), but also children as peer-educators (Anglin-Jaffe, Murris), as educators of their teachers (Johannesen, Haynes), and implicitly as educators of curriculum-advisors, policymakers and teacher-educators (Dixon, Murris).

These are all case studies that illustrate ways in which children act as educators of their peers and their student teachers/teachers. Such education takes place when children are engaged in projects that spill outside of the traditional classroom space or when children 
create alternative spaces. Children and young people can act as both official' and 'unofficial educators'. They are not always appointed as educators but they still act as such. There are two levels to this-sometimes they are officially appointed, as in peer education schemes, but actually it is the paid adult teachers who are still controlling and planning what is taught. In other cases, young people are not appointed officially, but in practice communicate to the official educators how they might be able to teach more effectively (Johannesen and Dixon). Sometimes, unofficial peer education has to be carried on out of sight of the teachers (Anglin-Jaffe).

The presentation of cases where education is possible, but does not always takes place, indicate that teachers and student teachers are often missing opportunities to be educated because they do not re-cognise or ac-knowledge the ways of knowing, or they doubt the authority of children to have something unique and distinctive to offer in that particular setting. Such a conception of education and what it means to teach challenge traditional conceptions. As Burbules (2008, p. 203) puts it:

...teaching is normally seen as an intentional activity directed toward the achievement of particular, explicit learning outcomes..., it is useful to be reminded of the crucial tacit dimension of teaching: the things that are taught that are not taught directly or intentionally; or, even, the things that are learned that are not in any simple or direct way "taught" at all.

For Burbules much of this kind of learning is 'caught' rather than 'taught'" and 'picked up' through a 'combination of observation, imitation, correction, and involvement with some on-going pattern of practice' (Burbules 2008, p. 203). Lenz-Taguchi (2010) argues that such practices can be made visible and subjected to research, documentation and critical reflection. It is this meta-stance to child-initiated practices that can be educative and open up possibilities to expose traditional views of teaching and learning as too technical—representing, reproducing and possibly normalising (Lenz-Taguchi 2010).

We conclude that it is possible for schools to be places where not only children, but also teachers, student teachers and teacher-educators can be educated through being alongside children; when listening to and observing children; when 'childing'; when age is less important than the nature or quality of the communicative relations and forms of educational activity that challenge more traditional representations of knowledge. These novel ideas inspire us to think about childlike encounters with childhood and knowledge, and to unlearn (to put into question) what is worth knowing.

Acknowledgments We would like to thank all those who have contributed to the creation of this special issue: the authors, the reviewers, and Simon Geschwindt who assisted with the translation and editing of Walter Kohan's paper and in particular Gert Biesta, the editor of Studies in Philosophy and Education, for his support and guidance.

\section{References}

Barrow, R. (2009). Was Peters nearly right about education? Journal of Philosophy of Education, 43(Supplement 1), 9-25.

Bradman, T., \& Ross, T. (2009). Michael. London: Andersen.

Burbules, N. C. (2008). Tacit teaching. In M. A. Peters, N. C. Burbules, \& P. Smeyers (Eds.), Showing and doing: Wittgenstein as a pedagogical philosopher. London: Paradigm Publishers.

Clark, A., McQuail, S. \& Moss, P. (2003). Exploring the field of listening to and involving young children. Research Report 445. London: DfES.

Frankham, J. (1998). Peer education: The unauthorised version. British Educational Research Journal, 24(2), 179-193. doi:10.1080/0141192980240205. 
Gaiman, N., \& McKean, D. (2003). The wolves in the walls. London: Bloomsbury.

Griscom, J. (1825). Monitorial instruction. New York, cited on http://constitution.org/lanc/mon_inst.htm. Accessed November 16, 2012.

Haynes, J., \& Murris, K. (2012). Picturebooks, pedagogy and philosophy. New York: Routledge.

Lakoff, G., \& Johnson, M. (1980). Metaphors we live by. Chicago: University of Chicago Press.

Lakoff, G., \& Johnson, M. (1999). Philosophy in the flesh: The embodied mind and its challenge to western thought. New York: Basic Books.

Lancaster, J. (1824). Westminster Review, v. 1, January, 1824, 53-55 cited on http://constitution.org/lanc/ psychmon.htm. Accessed November 16, 2012.

Lenz-Taguchi, H. (2010). Going beyond the theory/practice divide in early childhood education; Introducing an intra-active pedagogy. In G. Dahlberg \& P. Moss (Eds.), Contesting early childhood series. London: Routledge Falmer.

Murris, K. (2012). Epistemological orphans and childlike play with spaghetti: Philosophical conditions for transformation. Critical and Reflective Practice in Education, 3, 62-78 (http://www.marjon.ac.uk/ research/criticalandreflectivepracticeineducation/volume3/).

Peters, R. S. (1966). Ethics and education. London: George Allen \& Unwin.

Rudduck, J., \& Fielding, M. (2006). Student voice and the perils of popularity. Educational Review, 58(2), 219-231.

Sebba, J., \& Robinson, C. (2010). Evaluation of UNICEF's rights respecting schools award. Executive summary. University of Brighton and University of Sussex.

Stables, A. (2008). Childhood and the philosophy of education: An anti-Aristotelian perspective. London: Continuum Studies in Educational Research.

Thompson, C. (1995). How to live forever. London: Red Fox.

Turner, G., \& Shepherd, T. (1999). A method in search of a theory: Peer education and health promotion. Health Education Research Theory and Practice, 14(2), 235-247.

UNICEF (2010). Rights respecting schools. Steps to the Full Award http://www.unicef.org.uk/Documents/ Education-Documents/Steps_to_RRSA.pdf?epslanguage=en. Accessed January 29, 2013. 